\title{
Hrvatsko-slovenski odnosi na istočnom Žumberku ${ }^{1}$
}

\author{
Filip škiljan \\ Institut za migracije i narodnosti, Zagreb, Hrvatska \\ e-mail: filipskiljan@yahoo.co.uk
}

\author{
Barbara Riman \\ Inštitut za narodnostna vprašanja, Ljubljana, Slovenija \\ e-mail: barbara.riman@gmail.com
}

SAŽETAK Autori u tekstu donose informacije o hrvatsko-slovenskim odnosima na području Žumberka. Prostor granice u znanstvenom smislu do danas je vrlo rijetko promatran kroz iskaze pojedinaca koji žive u pograničnom prostoru, pa je stoga ovo istraživanje drugačije, budući da se temelji na doživljaju i iskustvima ljudi koji stanuju uz hrvatsko-slovensku granicu. Istraživanje je pokazalo da su stanovnici s jedne is druge strane granice mnogo više orijentirani jedni na druge nego što su povezani sa svojim regionalnim središtima. Granica je uvelike poremetila odnose Hrvata i Slovenaca s obiju strana, a ti odnosi do danas, usprkos ulasku Hrvatske i Slovenije u Europsku uniju, nisu vraćeni u nekadašnje okvire. Ovim se radom želi pokazati na koje su sve načine postojale veze između jednog i drugog prostora te koliko su te veze narušene nakon uspostave granice 1991. godine. U istraživanju je primijenjen povijesni i etnološki pristup, koji je vidljiv iz prikupljanja podataka iz matičnih knjiga umrlih i vjenčanih, odnosno iz metode usmene povijesti i prikupljanja priča kazivača. Na temelju matičnih knjiga umrlih i vjenčanih župa Stojdraga, Kalje, Mrzlo Polje i Sošice autor donosi podatke o intenzitetu kontakata Hrvata i Slovenaca u pograničnoj zoni Žumberka. Vidljivo je da su te veze bile uske tijekom gotovo petostoljetne povijesti u zajedničkoj državi, ali da su bračne veze bile ograničene zbog razlike u vjeroispovijesti. Iz provedenih intervjua na području Grada Samobora te Općine Žumberak vidljivo je da su stanovnici pograničnih zona bili oduvijek ekonomski, društveno i obiteljski vezani za obližnju Sloveniju.

Ključne riječi: Žumberak, hrvatsko-slovenski odnosi, Sošice, Samobor, pogranična zona.

${ }^{1}$ Rad je nastao u sklopu redovitog djelovanja Inštituta za narodnostna vprašanja iz Ljubljane, podružnica Rijeka 
"Nema izmedu nas razlike. Zovemo se susedima. Znate, Slovenci su pristojni ljudi. Oni nama nikada nisu vikali da smo Vlasi.«

\section{Geografsko područje Žumberka i prostor istraživanja}

Žumberak je prostor koji je prirodna granica između Hrvatske i Slovenije. Sjeveroistočna strana planine, koja pripada Sloveniji, strmija je i uža od jugoistočne i jugozapadne padine, koje pripadaju Hrvatskoj. Žumberak povezuje dinarski, predalpski i panonski prostor. U okviru regije središnje Hrvatske radi se o najvišem naseljenom prostoru. Sva su žumberačka naselja seoska, a prostor je u potpunosti omeđen hrvatsko-slovenskom granicom, i to od Gabrovice na sjeveroistoku, tokom Bregane do njena izvorišta te na jugu južnim vršnim nizom žumberačkog ravnjaka. Granica na jugu prelazi doline Slapnice i Kupčine prolazeći hrptom koji ih odvaja te do hrvatskoslovenske granice prati potok Kamenicu (Klemenčić, 1989.).

S obzirom na prirodno-geografska obilježja koja su predisponirala izoliranost, kao i značajke historijsko-geografskoga razvoja, Žumberak predstavlja specifično pogranično područje. Ono je rubno u odnosu na državni teritorij, ali i periferna nerazvijena zona u neposrednoj blizini Grada Zagreba. Periferije su upravo dijelovi teritorija i društva koje obilježava "rubnost" i u socijalno-gospodarskom i u kulturnom smislu (Popović i Radeljak, 2011.: 178).

Upravo je bogata povijest tog kraja utjecala na oblikovanje prostora kakav danas prepoznajemo. O povijesti Žumberka pisano je mnogo (Badovinac, 1896.; Popović, 1938.; Muraj, 1989.; Po Žumberku, 1989.; Hranilović, 1990.: 593-612; Uhač, 1996.; Crkvenčić, 2002.: 289-306; Zajc 2008.: 339-369; Bračika, 2015.; Vukšić, 2015.; Šćukanec, 2017.), ali tek su promjene u 20. stoljeću utjecale na odnose koji se razmatraju u ovom tekstu. Žumberak je bio isprva uključen u Zagrebačku biskupiju, ali je kasnije pripao bavarskim grofovima Andeks te je u 12. stoljeću ušao u kranjsku marku. Zagrebačkoj je biskupiji ostalo samo područje južnog Žumberka. Velike promjene na Žumberku uslijedile su nakon napada Osmanlija na područje današnje Bosne i Hercegovine i Hrvatske. Važnost Žumberka kao obrambenog područja bila je iznimno bitna za Kranjsku, pa ga je u 16. stoljeću otkupio kralj i car Ferdinand od crkvenih redova i organizirao državne posjede. Već 1530. godine stižu prvi Uskoci na područje sela Pećno, a u narednih devet godina doseljeno je na Žumberak iz Bosne, Hercegovine i Dalmatinske zagore nekoliko tisuća Uskoka. Radilo se o stanovniš- 
tvu vlaškog podrijetla koji su bili pravoslavne vjeroispovijesti. ${ }^{2}$ Car Ferdinand je tako 1540. godine osnovao Žumberačku kapetaniju sa sjedištem u Novom Gradu Žumberačkom. Nakon preuređenja Vojne krajine 1578. godine Žumberak je postao dijelom Slunjske kapetanije i podvrgnut je bio Karlovačkom generalatu. 1746. Žumberak je podijeljen u dvije kumpanije: Oštrčku, sa sjedištem u Kostanjevcu i Žumberačku, sa sjedištem u Siječevcu, a kasnije u Kaljama. Tek 1871. godine Žumberak je razvojačen, a zbog vlasničkih sporova s Kranjskom uključen je u Zagrebačku županiju tek 1881. godine. Kotarsko središte tada postaje Kostanjevac, a Sošice i Kalje postaju općinska središta. Od tada započinju intenzivne migracije Žumberčana i u prekomorske zemlje. Iseljavanje je nastavljeno kroz čitavo dvadeseto stoljeće. U Kraljevini SHS Žumberak je bio uključen u Zagrebačku oblast, a uvođenjem banovina 1929. godine u Savsku banovinu. 1931. godine izgubio je Općinu Radatovići, koja je priključena Dravskoj banovini. Nakon Drugog svjetskog rata Radatovići su vraćeni Hrvatskoj. Žumberak je upravo zbog granice izazvao (i izaziva) mnogo zanimanja, i to među hrvatskim, ali i slovenskim znanstvenicima. I upravo su istraživanja pokazala da je granična crta na Žumberku predstavljala nekadašnji kamen smutnje. Granica je između Kranjske i Hrvatske bila označena, međutim granica se prema shvaćanjima Žumberčana i Kranjaca nije podudarala, a pregovori oko njezinog definiranja odgađali su se godinama. Interes uključivanja Žumberka u Kranjsku Slovenci su vidjeli prije svega u šumskom bogatstvu Žumberačke gore. Koliko je to razgraničenje imalo (i ima) utjecaja potvrđuje i činjenica da i danas postoje legende koje su utkane u svakodnevni život lokalnog stanovništva a čija je središnja tema povezana upravo s razgraničenjem. Tako postoji legenda o nesretnoj ljubavi Žumberčanke i Kranjca, koja je nastala upravo zbog nemogućnosti dogovora o granici i o prijeporima između Kranjaca i Žumberčana na vrhu Žumberačke gore. Druga verzija legende govori o sukobima oko ispaše na livadama ispod Svete Gere. Za razliku od prve verzije legende, u drugoj verziji ljudi s obiju strana današnje granice dolaze do Krvavog kamena kako bi ustanovili gdje je granica. Kako ni Žumberčani ni Kranjci nisu željeli popustiti oko granice, došlo je svađe, pa i do boja. Naganjali su jedni druge i međusobno se ubijali oko stijene tako da su sa svih strana stijenu oblili krvlju. Kranjci su na kraju pobijedili svoje neprijatelje i granično kamenje postavili onako kako su smatrali da je ispravno, a kamen oko kojeg se vodio boj nazvali su Krvavim kamenom. ${ }^{3}$

2 Etnikon „Vlah“ ima vrlo široku apelativnu službu u značenju stočar, pastir i nomad. Teritorijalizacijom se postepeno razara dotadašnji katunarski ustroj vlaškog društva, a vjerskom i kulturnom asimilacijom Vlasi se, postepeno, do 16. stoljeća u najvećoj mjeri slaviziraju, odnosno postaju hrvatski ili srpski Vlasi/ vlasi, što znači da je u etničku strukturu hrvatskih i srpskih plemena ugrađen jedan stariji etnički sloj predslavenskog balkanskog stanovništva. Tako je proces asimilacije Vlaha u 16. stoljeću uglavnom okončan i pojam „vlah“ “ je od tada označavao jedino transhumantne stočare, a više nikako nije bio etnik. Danas se pojam „Vlah“ na Žumberku upotrebljava za grkokatoličko stanovništvo.

3 Priču o Krvavom kamenu moguće je naći na više mjesta: (Jagarić, 2008.: 240-242; Zajc, 2008.: 339340; Žumberački Uskoci, 2018.: 78-80. 
Žumberačko se pitanje intenzivno pokušavalo riješiti od 1881. godine, nakon definitivnog razvojačenja Vojne krajine, no ono se završilo ulaskom slovenskih i hrvatskih zemalja u Državu SHS, a potom u Kraljevinu SHS (Zajc, 2008.: 339-369). Upravo je ukidanjem Vojne krajine i započelo odseljavanje stanovništva sa Žumberka, i to zato jer su im do kraja ukinute sve povlastice koje su imali. Jedan dio Žumberčana odlazi u obližnja slovenska naselja i Zagreb, a drugi dio mogućnosti zarade pronalaze u prekooceanskim državama, da bi se 20-ih i 30-ih godina 20. stoljeća migracijski tokovi preusmjerili u Francusku i Njemačku. Nakon Drugog svjetskog rata dio Žumberčana odlazi zajedno s kolonistima u Slavoniju i u Srijem (tada npr. naseljavaju mjesto Berak kod Vukovara), a 60-ih godina sele u zemlje zapadne Europe. Najveći je broj stanovnika Žumberak imao 1930. godine, i to 18.990 . Od tada pa nadalje broj konstantno opada. U usporedbi s 1880. godinom 2001. broj stanovnika na Žumberku opao je za 60 \% (Štambuk, 1996.: 139-151; Crkvenčić, 2002.: 289-306; Popović i Radeljak, 2011.: 179-199).

Osim malog broja stanovnika, prostor Žumberka karakterizira i činjenica da je to gospodarski vrlo slabo razvijeno područje. Na slab razvoj utjecalo je više čimbenika, koji su se nakon 1991. godine i dodatno zakomplicirali.

Zbog oštre klime zastupljenost je obradivih kultura relativno slaba. Stanovništvo su privlačili slovenski krajevi, i to prije svega Novo Mesto, Brežice i Metlika, a na nerazvijenost je utjecala i blizina Zagreba. Žumberak je stoga bio, ali i ostao, periferna nerazvijena zona u socijalno-gospodarskom smislu (Popović i Radeljak, 2011.: 179199), a veća su se naselja razvijala rubno u odnosu na gorski masiv i to su: Jastrebarsko, Samobor, Metlika i Šentjernej (Bognar i Bognar, 2010.: 188).

Žumberačka gora, poput nekih drugih prirodnih granica koje postoje u slovensko-hrvatskoj granici, predstavlja prepreku povezivanju Hrvatske i Slovenije. Zanemarimo li cestu koja od Sošica vodi prema Kostanjevici, a koja je danas u lošem stanju i kojom se ne odvijaju gotovo nikakvi prometni tokovi, cijelom hrvatsko-slovenskom granicom malo je tako dugačkih prekida cestovnih veza. Osim slabe povezanosti sa slovenskim središtima s kojima je u prošlosti povezanost bila mnogo bolja nego $s$ hrvatskim središtima, i povezanost s nekadašnjim lokalnim općinskim središtima (Ozalj, Samobor, Jastrebarsko) vrlo je slaba. Odumiranje Žumberka vidljivo je i u činjenici da su do danas s radom prestale brojne škole i trgovine. Tako su trgovine 2008. godine postojale samo u Oštrcu i Stojdragi (koja danas više ne radi), a osnovne škole u Novom Selu Žumberačkom i Kostanjevcu, i to samo za učenike nižih razreda. Liječnik je prisutan u Kostanjevcu, a istočni dio Žumberka liječniku odlazi u Samobor, dok zapadni dio odlazi u Ozalj. Žumberak je danas podijeljen u četiri administrativne jedinice: općine 
Krašić i Žumberak (sa sjedištem u Kostanjevcu) te gradove Ozalj i Samobor. ${ }^{4}$ Brojna naselja na Žumberku više ne žive, već predstavljaju zapravo vikendaška naselja.

Kao i na drugim pograničnim prostorima duž slovensko-hrvatske granice, vidljivi su različiti procesi koji su postojali prije 1991. godine, a koji su zbog uspostave tvrde granice bili prekinuti. Sjećanje o tome postoji u kolektivnoj svijesti pograničnog stanovništva, koja seže daleko u prošlost.

Pri oblikovanju regije kakva je danas pripomoglo je postojanje, odnosno nepostojanje cestovne infrastrukture. Glavna žumberačka cesta od Stojdrage do Kostanjevca izgrađena je 1893. godine. I danas postoje naselja do kojih je pristup moguć jedino makadamskom cestom. Asfaltiranje najvažnije prometnice na Žumberku, koja ide od Bregane preko Stojdrage i Budinjaka do Kostanjevca, počelo je tek 1969. godine. Do 1975. bila je asfaltirana dionica od Bregane do Budinjaka. Godinu ranije, tj. 1974., asfaltirana je cesta od Kostanjevca do Sošica. Cijela trasa ceste od Budinjaka do Kostanjevca asfaltirana je tek 1994., dok je cesta od Hartja do Sošica asfaltirana tek 2011. godine. Da je ta cesta u punoj dužini bila asfaltirana prije, moguće je da bi danas demografska situacija bila nešto povoljnija (Turk, Šimunić i Živić, 2016.: 241-266).

Upravo je to i jedan od problema pograničnih prostora gdje infrastruktura prema hrvatskim urbanim mjestima nije do kraja razvijena i održavana, a stvaranje dviju neovisnih država otežalo je položaj stanovništva koje je bilo naučeno određenu egzistenciju rješavati u susjednoj državi, ali su to bili spriječeni zbog birokracije.

Život je na promatranom prostoru bio težak, te su dvije, danas pogranične, zajednice bile ovisne jedna o drugoj i na određeni im je način život tako bio olakšan. Postavljanjem granice 1991. godine dolazi do mnogih promjena koje nisu bile pozitivne. Granica je utjecala i na odnose na lokalnoj razini, te su zamijećeni sljedeći negativni učinci: (1) problem dvovlasništva i upravljanja njime, (2) problem uslužnih obrta i trgovine, (3) problem školstva, (4) problem prakticiranja vjere te (5) problem izmjene radne snage (Klemenčič, 2001.: 9-12). Pograničnom je stanovništvu otežana i osnovna prekogranična komunikacija, koja je postala teža ulaskom Slovenije u schengenski

\footnotetext{
${ }^{4}$ Stanovništvo Žumberka naziva se dvama imenima: za Žumberčane u zapadnom dijelu Žumberka upotrebljava se naziv fužinari, iako se oni, za razliku od Slovenaca uz prometnicu Novo Mesto - Metlika, nikada nisu bavili kovačijom ili ugljenom. Za stanovnike istočnog dijela Žumberka upotrebljava se naziv maslari ili šmolcari, budući da su se bavili proizvodnjom i prodajom masla. Fužinare su smatrali sposobnijim od maslara. (Popović, 1938.: 18-20) Prema kazivanju Mile Vranešića na Žumberku postoji i podjela po mentalitetu Žumberčana grkokatoličke vjeroispovijesti i Žumberčana rimokatoličke vjeroispovijesti. "Rimokatolici i grkokatolici na Žumberku su se razlikovali i po mentalitetu. Rimokatolici su bili kmetovi. Rimokatolici, i Hrvati i Slovenci, imaju kmetski mentalitet. Međutim Slovenci su svojim marljivim radom izgubili taj kmetski mentalitet. Grkokatolici su slobodnjaci i vojnici.»
} 
prostor krajem 2007. godine. To su procesi koje je moguće zamijetiti duž cijele slovensko-hrvatske granice. Potrebno je također napomenuti i da se nakon 30 godina stanovništvo još uvijek nije u potpunosti priviklo i suočilo s njima teškim situacijama. ${ }^{5}$

No i današnja istraživanja pokazuju da vrlo velik broj ljudi u zonama najbližima granici radi u inozemstvu, što pak upućuje na zapošljavanje stanovništva u tvornicama u blizini Metlike i Novog Mesta (Popović i Radeljak, 2011.:190).

\section{Kako istražiti pogranični prostor?}

Slovensko - hrvatska granica relativno je noviji fenomen, ali još uvijek nije prepoznat u slovenskim i hrvatskim znanstvenim krugovima kao nešto što možemo okarakterizirati i kao živi organizam koji se pod vanjskim čimbenicima oblikuje i ima svoje zakonitosti. I upravo u promatranju tih procesa važnu ulogu imaju granica i različiti procesi koji su uz nju nastajali. Pitanjem granice bavili su se geografi, povjesničari, ali i znanstvenici različitih drugih profesija i to s obiju strana granice (Knežević-Hočevar, 1996.: 7-17; Kržišnik Bukić, 1997.; Kržišnik Bukić, 1999.; Čapo-Žmegač, 2006.: 89-108; Zajc, 2008; Josipovič i Kržišnik Bukić, 2010.). Iz postojeće literature i istraživanja vidljivo je da su slovenski znanstvenici bili zainteresiraniji za tu temu.

Istraživanja problematike pograničnog prostora, granice i prekograničnih procesa do sada se u znanstvenim istraživanjima nisu temeljila na promatranju i analizi migracija i aktivnosti stanovništva pograničnog prostora, koje je uvođenjem granice 1991. godine bilo najviše pogođeno. Otvaraju se pitanja o načinu na koji oni gledaju na granicu te njihovim iskustvima. Upravo zato je važno u istraživanje uključiti i pojedince koji su živjeli i osjetili pogranični prostor prije i nakon 1991. godine. Povijesno-političke prilike Hrvatske i Slovenije, koje vrlo dugo nisu imale izraženu tvrdu granicu, utjecale su na činjenicu da se pogranični prostor treba promatrati kao povijesno-društvenokulturno jedinstven prostor. A opet, u tom slovensko-hrvatskom suživotu vidljivi su i mikroprostori, koji su pokazivali relativno jaku povezanost i okrenutost ka sebi i zatvorenost, a slično je i na promatranom prostoru Žumberka.

Pristup istraživanju te tematike već je djelomično bio objašnjen u radu „Rijeka i planina, granica i ljudi: studija slučaja života pograničnog stanovništva Donjekupske doline

${ }^{5}$ Koliko granica ometa svakodnevni život pokazuju i najnoviji slučajevi na relaciji Karlovačka županija - Bela Krajina, gdje su dnevni migranti spriječeni odlaziti na rad u Sloveniju zbog novog koronavirusa. Po povratku će biti podvrgnuti dvotjednoj kućnoj karanteni ili samoizolaciji, te neće moći napustiti Hrvatsku do isteka 14-dnevnog zdravstvenog nadzora, a time su spriječeni u povratku na posao. To je samo jedan od primjera ponekad teškog života u pograničnom prostoru (V. B./Hina, Od petka obustava dnevne migracije radnika iz Hrvatske u Belu Krajinu https://www.tportal.hr/vijesti/clanak/od-petkaobustava-dnevne-migracije-radnika-iz-hrvatske-u-belu-krajinu-20200312. 
i Žumberačkog gorja“, gdje je istraživano pogranično područje. Istraživanje provedeno na pograničnom području Žumberka izvedeno je u okviru djelovanja Inštituta za narodnostna vprašanja, podružnica u Rijeci te Instituta za narodnosti i migracije, gdje se sistematski kontinuirano željelo pristupati, i pristupa se, istraživanju procesa i života na pograničnom prostoru, koja iz ovdje navedenih zornih kutova još nisu provedena. Upravo je to i cilj ovog rada, prikaz suživota na pograničnom prostoru istočnog dijela Žumberka, jer su o zapadnom dijelu neki rezultati provedenog istraživanja već objavljeni (Riman i Škiljan 2018.: 401-439). Poseban će naglasak biti na prostoru Grada Samobora, odnosno na žumberačkoj zoni koja obuhvaća područje Grada Samobora (teritorij od Grdanjaca ${ }^{6}$ do Gornje Vasi). U samoborskoj zoni Žumberka nalaze se naselja: Bratelji, Brezovac Žumberački, Budinjak, Cerovica, Dane, Golubići, Gornja Vas, Kravljak, Novo Selo Žumberačko, Osredak Žumberački, Osunja, Poklek, Selce Žumberačko, Siječevac, Stojdraga, Šimraki i Tisovac. U istraživanju su promatrani i krajevi koji potpadaju pod današnju Općinu Žumberak (npr. Sošice).

Važni izvori za istraživanje pograničnog prostora kojemu do sada nije davana neka pretjerana pažnja su: analiza crkvenih povijesnih dokumenata te izvođenje intervjua.

Crkveni dokumenti u ovom istraživanju imaju vrlo važnu ulogu jer pokazuju doseljavanje stanovništva. Promatrano geografsko područje moramo promatrati kao prostor na kojem je fluktuacija ljudi bila slobodna, bez današnjih birokratskih i drugih problema. Župnici su u crkvenim dokumentima upisivali odakle bi stanovništvo određene župe došlo, te na taj način vidimo veze koje su inače promakle istraživačima koji su se bavili nekim drugim procesima. Analizom demografsko-povijesnih podataka dobivenih iz matičnih knjiga moguće je vidjeti povezivanje na temelju vjere (grkokatolici i rimokatolici), odnosno vidljivo je da su i mnogi drugi vanjski čimbenici (npr. cestovna infrastruktura) imali vrlo važan utjecaj. Upravo zato su bile pregledane matične knjige župa Kalje, Mrzlo Polje, Stojdraga i Sošice. Matične knjige vjenčanih i umrlih hrvatskih župa uz hrvatsko-slovensku granicu u razdoblju od gotovo stotinu godina na području današnje Zagrebačke županije ukazuju na međusobnu povezanost hrvatskih i slovenskih krajeva.

Posebno se važno čini i kolektivno sjećanje stanovništva s obiju strana današnje granice, kao i određene generalizacije, ukoliko su one postojale. Naime, kolektivno sjećanje nije statično, već se stalno mijenja pod različitim utjecajima: medija, političara, intelektualaca, organizacija, aktivista, vlastitog iskustva i mnogih drugih čimbenika (Tesser, 2013). Upravo zato su bili vrlo važni intervjui sa stanovništvom promatranog geografskog područja, jer su iznijeli stavove prema svojim susjedima.

\footnotetext{
${ }^{6}$ Naselje Grdanjci ne spadaju direktno u zonu Žumberka, već pod Podgorje (mirkoregija).
} 
Radom se želi ukazati na suživot na geografskom prostoru što ga je presjekla granica, evidentirati i veze koje su postojale među stanovništvom promatranog geografskog prostora. Radom se prikazuje suživot danas dvaju pograničnih prostora te kako stanovništvo hrvatskih krajeva gleda na susjedne krajeve. Istraživanje se temeljilo na prikupljanju životnih priča kazivača metodom polustrukturiranih dubinskih intervjua. $\mathrm{U}$ istraživanju je sudjelovalo devet kazivačica i kazivača, od čega s područja Grada Samobora njih osam, a s područja Općine Žumberak jedan. ${ }^{7}$

\section{Matične knjige - izvor za istraživanje nacionalno mješovitih brakova}

Matične knjige su javnopravni dokument koji predstavlja siguran izvor informacija za brojna znanstvena istraživanja (Vlahov, 1994.) i sve se češće koriste u suvremenim sociološkim, medicinskim i povijesnim istraživanjima. Podaci dobiveni iz matičnih knjiga vrlo su važni jer je na temelju njih moguće stvoriti detaljnu sliku određenog geografskog prostora i promatranog vremena. Prije svega su važni u povijesnoj demografiji. O važnosti matičnih knjiga u znanosti svjedoče brojni radovi. ${ }^{8}$ Prema Zakonu o arhivskom gradivu i arhivima osobni podaci postaju dostupni za korištenje 70 godina nakon nastanka i 100 godina od rođenja osobe na koju se odnose. U radu su analizirane matične knjige iz: grkokatoličke župe Svetog Petra i Pavla u Mrzlom Polju, grkokatoličke župe Svetog Jurja u Stojdragi, grkokatoličke župe Svetih Petra i Pavla u Sošicama te rimokatoličke župe Svetog Mihovila u Kaljama. Te su župe odabrane budući da su njihovi teritoriji smješteni uz samu granicu s današnjom Slovenijom, pa su i migracije na području tih župa bile intenzivnije nego u unutrašnjosti Žumberka, podalje od granice.

\section{Grkokatolička župa Svetog Petra i Pavla u Mrzlom Polju Žumberačkom}

Grkokatolička župa Svetog Petra i Pavla u Mrzlom Polju (Pavković, 1988.: 48-83; Kekić, 1994.: 90-94) stara je žumberačka župa, koja je 1782. godine obuhvaćala 14 sela i zaselaka. Te je godine župa imala 875 duša, a pod župu su potpadala sela Budinjak, Bratelji (vodilo se pod Budinjakom), Cerovica, Dani, Kordići (vodilo se pod Danima), Glušinja, Grič, Javor, Mrzlo Polje, Nova Sela, Osredak, Osunja, Preseka, Siječevac, Tisovac i Tomaševci. Tomaševci su bili najveće selo župe, koje je brojilo

\footnotetext{
7 Istraživanja su poduzeta u rujnu i listopadu 2019. godine na području Grada Samobora i Općine Žumberak. U istraživanju su sudjelovali I. Š., r. 1960. g., Budinjak; J. J., r. 1948. g., Jelenići (Budinjak); I. G., r. 1954. g., Samobor; r. I. H., 1945. g., Samobor; M. V., r. 1951. g., Novo Mesto; Z. M., r. 1960. g., Osunja; D. M., r. 1929. g., Osunja; S. Š., r. 1952. g., Hartje; I. Š., r. 1943. g., Šimraki.

8 Ovdje možemo navesti neke od radova koji su se bavili analizom stanovništva i kretanja stanovništva upravo na temelju podataka dobivenih iz matičnih knjiga: Bertoša, 2001.: 389-414; Bertoša, 2001.: 181198; Šövegeš Lipovšek, 2001.: 97-121; Balkovec, 2003.: 51-50; Bertoša, 2012.; Bilotas, 2016.: 77-87.
} 
179 stanovnika, dok je Cerovica s dvadeset žitelja bila najmanje selo. Činjenica je da je župa prije formiranja pećanske i stojdraške te grabarske župe obuhvaćala čitav istočni Žumberak. Granično selo između mrzlopoljske i radatovićke župe bilo je naselje Stari Grad. Malen broj brakova stanovnika promatranog pograničnog prostora sa stanovnicima koji žive na današnjem slovenskom pograničnom prostoru ukazuje na činjenicu da je vjera imala vrlo važan utjecaj pri odlukama za sklapanje brakova. Može se tvrditi da je izostanak rimokatoličko-grkokatoličkih brakova bio uvjetovan razlikom u obredu. U gotovo stotinu godina sklopljena su tek četiri takva braka, a prikaz je u tablici br. 1. Unatoč činjenici da je Mrzlo Polje pogranična župa, očito je da su bračne veze među stanovništvom danas slovenskog i hrvatskog pograničnog prostora bile vrlo rijetke.

Tablica 1.

Broj pojedinaca sa slovenskog prostora zabilježen u matičnim knjigama vjenčanih Mrzlo Polje Žumberačko9

\begin{tabular}{|l|l|c|}
\hline Mjesto stanovanja & Mjesto rođenja u Sloveniji & Ukupan broj \\
\hline Mrzlo Polje & $\begin{array}{l}\text { Gornja Ribnica u Kranjskoj (1900.) } \\
\text { (otišli u Samobor) }\end{array}$ & 1 \\
\hline Tomaševci & Lug u Kranjskoj (1903.) & 1 \\
\hline Glušinja & Obrežje (1928.) & 1 \\
\hline Kalje & Sveti Lovrenc (1928.) & 1 \\
\hline
\end{tabular}

Manji je broj osoba zabilježen i pri pregledu Matične knjige umrlih Mrzlo Polje 1858. - 1879., 1879. - 1896., 1897 - 1949. Prikaz je u tablici br. 2.

Tablica 2.

Broj pojedinaca sa slovenskog prostora zabilježen u matičnim knjigama umrlih Mrzlo Polje Žumberačko ${ }^{10}$

\begin{tabular}{|l|l|c|}
\hline Mjesto smrti & Mjesto rođenja i godina smrti & Ukupan broj \\
\hline Tomaševci & Planina u Sloveniji (1924.) & 1 \\
\hline
\end{tabular}

${ }^{9}$ HDA, Matična knjiga vjenčanih Mrzlo Polje 1858. - 1879., 1879. - 1896., 1897 - 1949.

10 HDA, Matična knjiga umrlih Mrzlo Polje 1858. - 1879., 1879. - 1896., 1897 - 1949. 
Nažalost, iz podataka dobivenih iz matičnih knjiga nije vidljivo ako su zabilježeni pojedinci iz slovenskog kraja bili iste vjere, odnosno grkokatolici. ${ }^{11} \mathrm{Na}$ relativno malen broj doseljenika vjerojatno je utjecao i položaj mjesta te loša prometna povezanost.

\section{Grkokatolička župa Svetog Jurja u Stojdragi}

Grkokatolička župa Stojdraga (Pavković, 1990.: 39-67) predstavlja najistočniju grkokatoličku župu na Žumberku. Župu Svetog Jurja mučenika u Stojdragi sačinjavaju tri naselja: Stojdraga, Kravljak i Selce. Prije utemeljenja stojdraške župe naselja koja danas potpadaju pod župu Stojdraga bila su isprva dio mrzlopoljske župe, a nešto kasnije dio župe Pećno. Župa u Stojdragi utemeljena je 1775. godine, kada i župa u Kaštu na zapadnom dijelu Žumberka. Župna crkva Svetog Jurja sagrađena je 1827. godine, neposredno nakon dolaska župnika Tade Šajatovića. Prema broju vjernika stojdraška je župa jedna od najmanjih grkokatoličkih župa. Godine 1831. brojila je svega 203 žitelja, od čega ih je 115 živjelo u Stojdragi, 39 u Selcu i 51 u Kravljaku. Kao i u mrzlopoljskoj župi i u stojdraškoj župi vidljivo je da je bračno povezivanje stanovništva iz danas slovenskih i hrvatskih pograničnih krajeva bilo rijetko. I dok u župi Mrzlo Polje Žumberačko nema nekih specifičnih veza s nekim slovenskim naseljima, ovdje je to vidljivije. Veze su bile uglavnom s naseljima Obrežjem i Velikom Dolinom u podnožju Gorjanaca. Prikaz je u tablici 3.

Tablica 3.

Broj pojedinaca sa slovenskog prostora zabilježen u matičnim knjigama vjenčanih župe Stojdraga 1885. - 1901., 1903. - 1939.12

\begin{tabular}{|l|l|c|}
\hline Mjesto stanovanja & Mjesto rođenja & Ukupan broj \\
\hline Kravljak & Obrežje (1893.), Prilipe (1903.) & 2 \\
\hline Stojdraga & $\begin{array}{l}\text { Obrežje (Velika Dolina) (2X) } \\
\text { (1912.), Obrežje (1913.) }\end{array}$ \\
\hline
\end{tabular}

Ali svejedno je broj pojedinaca koji su se doselili u hrvatske krajeve izuzetno malen. To potvrđuju i podaci iz matične knjige umrlih. Prikaz je u tablici br. 4.

\footnotetext{
${ }^{11}$ Na području Slovenije postoje svega dvije grkokatoličke župe oslonjene na područje Žumberka. Radi se o grkokatoličkim župama u Dragama i u Metlici. Grkokatolici su stoga mogli doći iz tih dviju župa. 12 HDA, Matična knjiga vjenčanih župe Stojdraga 1885. - 1901., 1903. - 1939.
} 
Tablica 4.

Broj pojedinaca sa slovenskog prostora zabilježen u matičnim knjigama umrlih župe Stojdraga 1880, 1885. - 1901., 1903. - 1939. ${ }^{13}$

\begin{tabular}{|l|l|c|}
\hline Mjesto smrti & Mjesto rođenja i godina smrti & Ukupan broj \\
\hline Stojdraga & Obrežje (1939.) & 1 \\
\hline
\end{tabular}

Osim vjeroispovijesti, u ovom je slučaju na malen broj doseljenih stanovnika utjecalo i negostoljubivo podneblje, težak život i nerazvijenost promatranog područja.

\section{Grkokatolička župa Svetih Petra i Pavla u Sošicama}

Prema povijesnim podacima na područje današnjih Sošica (Pavković 1987.: 34-74) novi su se doseljenici naselili 1530. i 1531. godine. Isprva su na Žumberku postojale svega dvije grkokatoličke župe: ona u Radatovićima na zapadnom dijelu Žumberka i ona u Mrzlom Polju za istočni dio Žumberka. U 18. stoljeću osnovane su još dvije župe, i to u Badovincima i u Pećnom. Pod župu Svetoga Nikole u Badovincima potpadala su i sela današnje sošičke i kaštanske župe, dok su pod Pećno potpadala naselja današnje stojdraške, pećanske i grabarske župe. Sredinom 18. stoljeća formirana je današnja župa u Sošicama. Župa se spominje 1746. godine, a osnovana je navodno tri godine ranije, 1743. godine. Postojeća crkva Svetih Petra i Pavla sagrađena je između 1750. i 1775. godine. Župni dvor u Sošicama podignut je 1907. godine. U vrijeme Drugog svjetskog rata spaljen je župni dvor kao i samostan časnih sestara Bazilijanki.

Na prostoru ovdje spominjane župe nalaze se i na vrhu Žumberačke gore, na Svetoj Geri, jedna pored druge kapela Svetog Ilije (grkokatolička) i kapela Svete Gere (rimokatolička). Zanimljiva je činjenica da je kapela Svetog Ilije na slovenskom tlu, a Svete Gere na hrvatskom tlu. Za razliku od mrzlopoljske i stojdraške župe, koje su imale vrlo malo brakova između osoba rođenih na današnjem slovenskom i hrvatskom pograničnom prostoru, na području župe Sošice bilo je više hrvatsko-slovenskih brakova. Činjenica je da se jedan dio onih koji su se vjenčali u Sošicama odselio u slovenska naselja pod Gorjancima, gdje je život ipak bio nešto lakši, odnosno gdje su veze s većim naseljima bile učestalije i bolje. Veze su vidljive s naseljima obližnje Dolenjske i Bele krajine (posebno sa Šentjernejem, gdje su Sošičani odlazili na sajmove). Prikaz je u tablicama br. 5 . i br. 6 .

13 HDA, Matična knjiga umrlih župe Stojdraga 1880, 1885. - 1901., 1903. - 1939. 
Tablica 5.

Broj pojedinaca sa slovenskog prostora zabilježen u matičnim knjigama vjenčanih Sošice 1885. - $1940 .{ }^{14}$

\begin{tabular}{|l|l|c|}
\hline $\begin{array}{l}\text { Mjesto } \\
\text { stanovanja }\end{array}$ & Mjesto rođenja i godina vjenčanja & Ukupan broj \\
\hline Sopote & $\begin{array}{l}\text { Vukovci (1894.), Cerus (?) (1898.), Vinica (1920.), Trbovlje (1949.) (otišli } \\
\text { u Trbovlje), Gornje Vrpolje (Novo Mesto) (1950.) (otišli u Gornje Vrpolje) }\end{array}$ & 5 \\
\hline $\begin{array}{l}\text { Starigrad } \\
\text { Žumberački }\end{array}$ & Gornja Prekopa (1897.) & 1 \\
\hline Malinci & Hrast (1901.) (otišli u Hrast) & 1 \\
\hline Jezernice & Rosalnice (1918.) (otišli u Rosalnice) & 1 \\
\hline Dančulovići & Gornje Vrpolje (1927.) & 1 \\
\hline Sošice & $\begin{array}{l}\text { Hrib (1929.), Šentjernej (1929.), Skrilje (1930.), Škocjan (1949.) (otišli u } \\
\text { Škocjan), Maribor (1949.) (otišli u Maribor), Škocjan (1950.) }\end{array}$ & 6 \\
\hline Kordići & Trbovlje (1930.) & 1 \\
\hline Cernik & Kostanjevica (1949.) (otišli u Kostanjevicu) & 1 \\
\hline
\end{tabular}

I dok je broj pojedinaca koji su se doselili, a potom naknadno otišli na prostor današnje Slovenije puno veći nego u do sada analiziranim župama, broj je umrlih u prosjeku kao i u prije spomenutim župama. Prikaz je u tablici br. 6.

Tablica 6.

Broj pojedinaca sa slovenskog prostora zabilježen u matičnim knjigama umrlih Sošice 1885. - 1940. ${ }^{15}$

\begin{tabular}{|l|l|c|}
\hline Mjesto smrti & Mjesto rođenja i godina smrti & Ukupan broj \\
\hline Sopote & Krašnji Vrh (1918.) & 1 \\
\hline Drage & Drage (1918.) & 1 \\
\hline Stari Grad Žumberački & Šentjernej (1921.) & 1 \\
\hline
\end{tabular}

Veći broj pojedinaca koji se doseljavalo to je vjerojatno učinio zbog bolje prometne povezanosti promatrane župe u usporedbi s prethodnima te zbog činjenice da su se stanovnici susretali na sajmovima u Dolenjskoj i Beloj Krajini.

\footnotetext{
${ }^{14}$ HDA, Matična knjiga vjenčanih Sošice 1885. - 1940.

15 HDA, Matična knjiga umrlih Sošice 1885. - 1940.
} 


\section{Rimokatolička župa Svetog Mihovila u Kaljama}

Jedina rimokatolička župa čije su matične knjige bila analizirane župa je sv. Mihovila u Kaljama (Kekić, 1992.: 38-66). Crkva je sagrađena 1672. godine, a proširena 1821. godine. Uz ovu župu u Žumberku postoje još rimokatolička župa u Žumberku (Sveti Nikola) i rimokatolička župa u Oštrcu, kojoj je sjedište u Kostanjevcu. Sve su te župe do kraja 18. stoljeća (odnosno do formalnog pripajanja Žumberka Zagrebačkoj biskupiji) imale uglavnom slovenske svećenike. Zupa u Kalju formirana je 1789. godine, a do tada je potpadala pod župu u Žumberku. U početku je vođena kao samostalna kapelanija, a od 1821. godine službeno je samostalna župa. Župa Kalje proteže se u dužini od 16 kilometara uz glavnu prometnicu Samobor - Kostanjevac. Njezin istočni dio započinje zaseokom Drmići kod Stojdrage, a završava na zapadu selom Hartje. Župa je 1808. godine imala 562 župljana, a broj se postepeno povećavao pa je 1875. narastao na 1098. Najveći broj župljana bio je 1929., kada je župa brojila 1799 stanovnika, a nakon toga broj počinje padati. Tako ih je između 1966. i 1974. svega 1000, a 1996. svega 365. Godine 2014. župa je brojila tek 140 župljana.

Vidljivo je da je na odluku o osnivanju obitelji te doseljavanju iz danas pograničnih prostora Republike Slovenije i Republike Hrvatske veliku ulogu imala vjera. Prikaz je u tablici br. 7 .

Tablica 7.

Broj pojedinaca sa slovenskog prostora zabilježen u matičnim knjigama vjenčanih Kalje 1888. - $1949 .{ }^{16}$

\begin{tabular}{|l|l|c|}
\hline $\begin{array}{l}\text { Mjesto } \\
\text { stanovanja }\end{array}$ & Mjesto rođenja i godina vjenčanja & $\begin{array}{c}\text { Ukupan } \\
\text { broj }\end{array}$ \\
\hline Kalje & $\begin{array}{l}\text { Ober Planina u Kranjskoj (1889.), Velika Dolina (1904.), Črešnjevec (1904.) (odselili } \\
\text { u Černeču Vas) }\end{array}$ & 3 \\
\hline Gornja Vas & $\begin{array}{l}\text { Drama (župa Svetog Bartolomeja u Kranjskoj) (1890.) Klonivik (?) (Kranjska) } \\
\text { (1903.) (smješten u Starom Gradu), Velika Dolina (1906.), Šentjernej (1909.), Brezje } \\
\text { (1927.) }\end{array}$ & 8 \\
\hline Javor & Vinica (župa Šmarjeta, Dol) (1928.) & 1 \\
\hline Stupe & Šentjernej (1935.) & 1 \\
\hline Cerovica & Prušnja Vas (1925.) & 1 \\
\hline Novo Selo & Planine (župa Sveti Križ) (1924.) (otišli u Planine), Orehovec (1939.) & 2 \\
\hline Višći Vrh & Črenšovec (župa Sveti Križ u Kranjskoj) (1893.), Sveti Križ (1908.) & 2 \\
\hline Grič & Male Vodenice (Kostanjevica) (1894.) & 1 \\
\hline $\begin{array}{l}\text { Petričko } \\
\text { Selo }\end{array}$ & Dobec (Kostanjevica) (1894.), Raka (1907.), St. Limbert (1910.) & 3 \\
\hline Hartje & Sveti Križ pri Kostanjevici (1907.) & 1 \\
\hline
\end{tabular}

16 HDA, Matična knjiga vjenčanih Kalje 1888. - 1949. 
I dok se do sada govorilo o četirima ili manje doseljenih pojedinaca, ovdje je riječ o relativno velikom broju. Zabilježene su, naime, 23 osobe.

I broj umrlih podrijetlom iz slovenskih krajeva znatno je veći. Na to ukazuje tablica br. 8 .

Tablica 8.

Broj pojedinaca sa slovenskog prostora zabilježen u maticama umrlih župe Kalje 1858. - 1878., 1878. 1887., 1888. - 1920., 1921. - 1926. ${ }^{17}$

\begin{tabular}{|l|l|c|}
\hline Mjesto smrti & Mjesto rođenja i godina smrti & Ukupan broj \\
\hline Gornja Vas & $\begin{array}{l}\text { Žužemberk (1859.), Kostanjevica } \\
(1918 .)\end{array}$ & 2 \\
\hline Slapnica & $\begin{array}{l}\text { Sant Skocian in Carniola (1865.), } \\
\text { Raduče kod Kř̌kog (1899.) }\end{array}$ & 2 \\
\hline Petričko Selo & $\begin{array}{l}\text { Čaber in Carniola (1871.), Stein } \\
\text { (Kranjska) (1916.) }\end{array}$ & 1 \\
\hline Novo Selo & Planina (parocchia Crucis) (1874.) & 1 \\
\hline Hartje & Brlog u Kranjskoj (1890.) & 1 \\
\hline Kalje & $\begin{array}{l}\text { Globočice (župa Kostanjevica) } \\
(1898 .)\end{array}$ \\
\hline
\end{tabular}

Veći broj brakova sklopljen je sa stanovnicima iz obližnjih slovenskih naselja (Velika Dolina, Planina, Vrtača, Prušnja Vas, Šentjernej), ali je bilo brakova sa stanovnicima iz udaljenijih naselja, primjerice Žužemberka. Evidentno je da su se nacionalno mješoviti brakovi lakše sklapali između osoba iste vjeroispovijesti i istog obreda.

Kao što je vidljivo iz matičnih knjiga, prekogranični brakovi nisu bili učestali na području istočnog dijela Žumberka. Naime, planina je ipak stvarala određenu prepreku, a utjecala je i različita vjera (grkokatolici-rimokatolici). M. V. (Stojdraga), grkokatolički župnik u Stojdragi, kazuje o broju nacionalno mješovitih brakova:

"Na sajmovima su se Žumberčani i Slovenci upoznavali, prijateljevali, konačno se zaljubljivali i ženili. Pazilo se jedino da ne bude krvnoga srodstva, ali se pazilo i na crkveno-obrednu pripadnost, jer iako je život kod grkokatolika i rimokatolika bio sličan, nije bio jednak. U grkokatoličkom obredu vjenčanja žena se zaklinje na četiri stvari: ljubav, vjernost, bračno poštenje i poslušnost mužu, dok kod rimokatolika nema ovoga posljednjega. Pazilo se i na kumstvo, a pogotovo je to bilo važno kod dva kalendara i dvostrukog svetkovanja blagdana.«

${ }^{17}$ HDA, Matična knjiga umrlih Kalje 1858. - 1878., 1878. - 1887., 1888. - 1920., 1921. - 1926. 
O doseljavanju Slovenaca na Žumberak, koje je bilo vrlo rijetko, kao što je vidljivo i iz matičnih knjiga umrlih i vjenčanih, govori M. V. (Stojdraga): „U Žumberak su se samo iznimno priženili slovenski zetovi. Bili su to uglavnom obrtnici i majstori: cimermani, opančari, sotlari (kožari). Slovenci su po Žumberku radili u vrijeme po šumama na sječi. Kod Slovenaca je bila politika policentričnog razvoja države tako da su se i manji gradići pod obroncima Gorjanaca razvijali.»

I. Š. (Budinjak) kazuje o brakovima: „Što se tiče nacionalno mješovitih brakova treba istaknuti da su na Žumberak slovenske cure vrlo rijetko odlazile. Prije su se Žumberčani i Žumberčanke spuštali u podnožje Gorjanaca i ondje tražili partnere/ice.« J. J. (Jelenići) spominje da je »...mješovitih brakova bilo, ali vrlo malo. Svega nekoliko u selima uz granicu - u Osunji, Cerovici i Prisjeki«. I. G. (Grdanjci) se čini da su »Slovenke bile pitomije od naših cura. Naše su cure rijetko išle za Slovence.«I. Š. (Šimraki) tvrdi da su cure mnogo češće znale odlaziti u Sloveniju, nego što su Slovenke dolazile na Žumberak.

Kazivači su također točno znali u koju se kuću udala koja Slovenka. Tako I. H. (Samobor) govori o broju brakova u Gornjoj Vasi. "Slovensko-hrvatskih brakova je bilo malo. U Gornjoj Vasi je bila udana tek jedna Slovenka, kod I. Š. (Budinjak)« Z.M. ističe također mali broj nacionalno i vjersko mješovitih brakova: »Brakovi su se uglavnom sklapali unutar vjernika grkokatoličke vjeroispovijesti.«

O povezanosti i na drugim razinama, koja je postojala, iako u manjoj mjeri nego u onim pograničnim prostorima gdje nije bilo prirodnih prepreka, govore i sjećanja pojedinaca koji su život proveli na promatranom prostoru.

\section{Iskazi kazivača o životu Hrvata i Slovenaca na području istočnog Žumberka}

Hrvatsko-slovenski odnosi uz granicu Hrvatske i Slovenije u Zagrebačkoj županiji predstavljaju vrlo dobar primjer kvalitetnih dobrosusjedskih odnosa. Iskazi kazivača koji su sudjelovali u istraživanju spomenutog fenomena u pograničnoj zoni Žumberka koji pripada teritoriju Grada Samobora govore o tim kvalitetnim odnosima koji traju već stoljećima. Kao što je već bilo napomenuto u članku, u istraživanju je sudjelovalo devet kazivača.

Pitanja su bila grupirana prema temama koje su se do sada pokazale kao značajne na pograničnom prostoru. Teme su razgovora bile: mjesta susreta, imovinsko-pravni odnosi, cestovna infrastruktura i povezanost, veze između Žumberka i Gorjanaca, iseljavanje, granica između Hrvatske i Slovenije na Žumberku, prekogranični brakovi te jezične sličnosti. Istraživanje je provedeno tijekom rujna i listopada 2019. godine, a kazivači su ispitivani na Žumberku i u Samoboru. 
Tijekom analize prikupljenih sjećanja vidjelo se da su neke teme i događaji ostali u posebnom sjećanju među kazivačima.

\section{Sajmovi, proštenja, vinogradi i putevi}

Tako su sajmovi i proštenja bili izuzetno važni društveni događaji na kojima se susretalo stanovništvo današnjeg pograničnog prostora. Sajmovi i proštenja bili su mjesto sastajanja, dogovaranja poslova, trgovanja i upoznavanja.

Žumberački i „kranjski“ sajmovi uglavnom su bili vezani za stoku koju se prodavala i preprodavala. Najpoznatiji sajam na Žumberku bio je u Budinjaku, a drugi po posjećenosti bio je u Sošicama. I. Š. (Budinjak) kod pitanja o susjedskim odnosima i povezivanju među Slovencima i Hrvatima prije svega se prisjeća sajmova: »Moja sjećanja na zajednički život Hrvata i Slovenaca na Žumberku uglavnom su vezana za žumberačke sajmove koji su se odvijali u Budinjaku kod crkve Svete Petronile (Svete Petke). Na tim sajmovima bilo je oko $50 \%$ Slovenaca i oko $50 \%$ naših ljudi.«

O važnosti sajmova za normalan suživot govore i drugi ispitivači. Tako M. V., grkokatolički župnik u Stojdragi, govori:

»Mjesto sastajanja Slovenaca i Hrvata bili su sajmovi. Kako je bilo sajmova u Metliki tako ih je bilo i na istočnom Žumberku, u Sošicama i u Budinjaku, a na slovenskoj strani u Šentjerneju. Razlika između metličkog i budinjačkog, odnosno sošičkog sajma je bila ta što su na metlički sajam dolazili talijanski nakupci stoke. Do onuda se moglo doći željeznicom, a na Žumberku to nije bilo moguće. U Sošicama su se sajmovi održavali do kraja šezdesetih, a u Budinjaku do kraja osamdesetih godina prošloga stoljeća. Sošice su bile više vezane za Sloveniju i za Šentjernej, odakle su redovito na sajam dolazili Slovenci. Sošičani su znali kupovati stoku u Sloveniji i onda je u Metlici preprodavali kao svoju, žumberačku stoku, koja je bila cjenjenija od slovenske stoke.»

J. J. (Jelenići) ističe slične podatke, i to da su stočni sajmovi bili mjesto trgovine između Hrvata i Slovenaca te da su na njih dolazili trgovci iz udaljenih područja:

"Sajam u Budinjaku bio je jednom mjesečno i to ponedjeljkom. Na njega su dolazili iz svih okolnih sela - od Sošica do Stojdrage, a iz Slovenije su stizali čak iz Kostanjevice i sela oko Kostanjevice. Naši su odlazili na sajam u Brežice. Činjenica je da smo mi Žumberčani bili vezani za Kranjce i zanatski jer se do 1871. godine, odnosno do razvojačenja Vojne krajine nismo smjeli baviti zanatima." 
S. Š. iz Hartja pak ističe kako su:

"...na sajmove odlazili najčešće u Šentjernej, a imali smo najbliskije veze s Kostanjevicom na Krki. U Šentjerneju su sajmovi bili dva puta mjesečno - jednom prvu subotu nakon prvog u mjesecu, a drugi put prvu subotu nakon petnaestog u mjesecu. Odlazio sam tamo kupovati stoku. Na sajmovima bismo razgovarali po naški, odnosno ja bih govorio našim žumberačkim dijalektom, a oni svojim dijalektom slovenskog jezika i sve smo se razumjeli. Znate, ovi Podgorci, oni su slični našim ljudima. Oni će te kao i Žumberčani počastiti i pogostiti, dok te Poljci (misli na stanovnike koji su smješteni već uz dolinu Save, op.a.) neće počastiti. Oni su kao i Štajerci, škrti.»

Kao što je vidljivo iz sjećanja, upravo su sajmovi imali značajnu ulogu kako u samoj gospodarstvenoj djelatnosti tako onda i u društvenoj povezanosti. Ovdje je svakako potrebno spomenuti i prodavaonice koje su imale vrlo važnu ulogu. Potrebno ih je promatrati kao mjesto susreta, mjesto gdje je bilo moguće doći do različitih informacija. Prodavaonice i trgovine imale su važan položaj prije svega do 1991. godine. I. Š. (Šimraki), jedan od kazivača, godinama je imao trgovinu u Stojdragi. Činjenica je da su osamdesetih i početkom devedesetih godina dvadesetog stoljeća postojale još i trgovine u Budinjaku i u Gornjoj Vasi, ali je starijim Žumberčanima bilo nemoguće doći do njih. Stoga je Ivan Šimrak proizvode razvozio kamionom po žumberačkim selima gdje nije bilo trgovine. Na zatvaranje trgovina utjecali su i procesi koje su kazivači spominjali u svojim sjećanjima, prije svega migracije, odnosno odlazak stanovništva u razvijenije krajeve. Pojedina su se sela snabdijevala i u Sloveniji, osobito ona koja su bila smještena uz samu hrvatsko-slovensku granicu. Prisjeća se: „U moju trgovinu u Stojdragi dolazili su i Slovenci iz obližnjih slovenskih zaselaka (npr. selo Gramci kojima je bliže bilo doći do Stojdrage u trgovinu nego do prvog slovenskog naselja gdje postoji trgovina).»

Sjećanja na važnost trgovine ima i Nada Severović, učiteljica u Stojdragi početkom šezdesetih godina dvadesetog stoljeća. Ona ističe kako su trgovine tada bile u Samoboru i u Brežicama i kako je ona češće odlazila u trgovinu u Brežice nego u Samobor, i to pješice iz Stojdrage. Na to ju vežu i lijepa sjećanja, pa se tako prisjetila da je u Brežicama kupila i svoj prvi bicikl, a dječaci iz stojdraške škole pomogli su joj odgurati ga do Stojdrage (Severović, 2000.: 91-94).

I danas stanovništvo u Sloveniju najviše odlazi radi posla i opskrbe, a prema istraživanju koje je provedeno 2008. godine, čak se više od $80 \%$ ispitanika živežnim namirnicama i svakodnevnim potrepštinama opskrbljuje u Metliki, Novom Mestu ili Suhoru (Popović i Radeljak, 2011.: 192). 
U povezivanju i suživotu stanovništva vrlo su važnu ulogu imala i proštenja, upravo iz sličnih razloga koji su zabilježeni i pri sajmovima, a ona su bila dobro posjećena, i to kako kazuje M. V. (Stojdraga):

"...ne zbog vjerskih potreba, već zbog toga što su se tom zgodom dogovarali poslovi. Domicilni župnici su poticali ovakav duh proštenja, pa su na njih dolazili i rimokatolici i grkokatolici, bez obzira čije je proštenje bilo. Tradicionalna proštenja su bila Jurjevsko na Stojdragi, Rokovsko i Petrovsko na Budinjaku i Petrovsko na Sošicama. Od obnove svetišta Svetog Ilije na Svetoj Geri i nekoliko zajedničkih druženja bi se održalo i na toj lokaciji. Žumberčani su na proštenja odlazili u Sloveniju: u Kvaternicu kod Kostanjevice, a posebno u Lurd kod Šentjerneja."

O proštenjima govori i J. J. (Jelenići): "Sastajali bismo se i kod pojedinih proštenja. Tako se u Stojdragi slavi Jurjevdan. Taj smo dan zvali i Kranjski dan budući da su Kranjci dolazili u velikom broju na to proštenje. Ljudi su rado dolazili zbog toga što su se pekle ovce i koze na ražnju, a to kod njih u Sloveniji nije bio slučaj. «I I. Š. (Šimraki) govori o važnosti proštenja, osobito u Stojdragi: "Poseban događaj u Stojdragi je bilo jurjevsko slavlje. Slabo bi mi delali toga dana da nije bilo Slovenaca koji su dolazili. Najviše su dolazili zbog janjetine i zbog druženja. Bili su janjci, odojak i muzika.«I. G. (Grdanjci) se pak prisjeća:

»najveći broj poznanstava između Hrvata i Slovenki ostvarivao [se] na proštenjima i na zabavama. Na proštenja i u gostionice su dolazili i muškarci i žene. Do Vilinskih jama, gostionice u Grdanjcima, dolazili su Slovenci iz Brežica i okoline. Po mentalitetu su se Slovenci razlikovali od nas Hrvata. Bili su bučniji i više su pili. Na sajmovima i proštenjima prodavali su se licitari i pekli su se janjci. Mi smo janjce zvali žumberačkim puranima. Slovenci su redovito dolazili na janjetinu jer toga kod njih nije bilo.«

Upravo je regionalna marginalizacija te teško povezivanje $s$ većim mjestima u Hrvatskoj doprinijelo gravitaciji stanovništva ka slovenskim naseljima. I. Š. (Budinjak) ističe kako su:

"...ljudi gore na Žumberku bili slabo povezani sa svojim centrima u Samoboru i Jastrebarskom, pa su stoga vrlo često bili oslonjeni na Sloveniju. Nekada su prometnice između Hrvatske i Slovenije prolazile i Žumberačkom gorom. Bili su tu prolazi kod Selca kod Stojdrage, kod Osunje, na Novom Selu i na Pokleku. Danas je ostao aktivan još samo prolaz na Novom Selu, dok ove ostale rijetko upotrebljavaju i domaći ljudi. Rodilište je, recimo, u vrijeme socijalizma bilo u Brežicama. Čak 50 \% Samoboraca, ali i dijela Žumberčana, rođeni su u Brežicama jer je tamo bilo bliže otići nego u Zagreb.» 
S tim fenomenom izoliranosti i slabe prometne povezanosti susreću se i drugi pogranični krajevi koji su 1991. godine na određeni način ostali, zbog loših i slabo uređenih prometnica, amputirani od hrvatskih urbanih središta, a opet i od slovenskih upravo zbog uvedene tvrde granice. Slična je situacija zabilježena i u drugim pograničnim krajevima. Rodilišta su jedan od pokazatelja prometne povezanosti i blizine, pa su tako u pograničnom prostoru Gorskog kotara žene često odlazile u rodilište u Postojnu, upravo zbog bolje prometne povezanosti.

Z. M. (Osunja) ističe činjenicu da su Žumberčani oduvijek bili više oslonjeni na slovensku stranu Gorjanaca, odnosno gradiće u obližnjoj Sloveniji. Povezano je to sa svakodnevnim životnim potrebama: "Na Budinjak se odlazilo liječniku zbog nekih manjih problema, ali da je bolnica bila u Brežicama. Do Brežica se odlazilo preko Prušnje Vasi gdje je bio autobus. U Kostanjevici nam je bio zubar.«

O odlascima liječniku u Kostanjevicu govori I. H. (Samobor): „U Kranjsku smo odlazili u trgovinu i kod liječnika. Od Gornje Vasi nam je trebalo oko sat i pol pješice do Kostanjevice."

M. V. (Stojdraga) pak govori i o današnjoj slaboj prohodnosti puteva koji vode prema Sloveniji. "Žumberčani su bili iznimno slabo prometno povezani do 1890. godine. Do tada su svi radije odlazili u Brežice, u Metliku, u Šentjernej jer im je to bilo bliže. Tek izgradnjom prometnice od Gabrovice prema Stojdragi i dalje do Kostanjevca i od Sošica do Kostanjevca ljudi su radije odlazili u Jastrebarsko, Samobor i Karlovac. Nekadašnji putevi prema Sloveniji su zapušteni.«

Prema Klemenčič (2001:12), rezultati provedenog anketnog istraživanja pokazuju da je na pitanje o posjedovanju zemljišta u Sloveniji čak 50\% kućanstava odgovorilo pozitivno, a 72,3\% vlasnika zemljišta u Sloveniji i obrađuje. I upravo to pokazuje da je povezanost stanovništva i na taj način bila vrlo velika. Vlasnici zemlje često su se susretali i s birokratskim problemima, pa je to ujedno i jedan od većih problema. Vladimir Klemenčič upravo to dvovlasništvo i upravljanje njime navodi kao jednu od razina na kojima su zamijećeni negativni učinci. S tim problemima su se susretali i stanovnici pograničnog prostora koji su imali (i imaju) posjede s obiju strana granice. Žumberčani su imali svoju zemlju na slovenskoj strani Gorjanaca. Radilo se u najvećoj mjeri o vinogradima u poznatom vinorodnom kraju Gadovoj peči. I. Š. (Budinjak) se prisjeća:

"...svi vinogradi Žumberčana koji su živjeli uz prometnicu Bregana-Gornja Vas bili su na slovenskoj strani. Najpoznatiji vinogradi su bili u Gadovoj peči. Slovenci su prodavali svoju zemlju u Gadovoj peči našim ljudima i oni su ondje gradili svoje klijeti u kojima su proizvodili poznati ‘Cviček'. Imao sam jednog prijatelja čiji je djed bio iz Kravljaka i koji je 1927. godine sagradio klijet u vinogradu u Gadovoj peči. Imali su ondje oko 8000 trsova, kuću, staju, sjenik i nadstrešnicu s prešom. Njihova obitelj odlazila je ondje obrađivati vinograd, a sa sobom su vodili volove i stoku te su ondje boravili i po desetak dana dok nisu sav posao obavili. Bili su to pravi mali stanovi.“ 
J. J. (Jelenići) ističe da su »oni koji su bili južno od prometnice Bregana - Gornja Vas imali svoje vinograde na Plešivici kod Svete Jane, dok su oni uz cestu i sjeverno od prometnice dobivali vinograde na prostoru Slovenije«. O Gadovoj peči govori i I. G. (Grdanjci): »U Gadovoj su peči Žumberčani imali svoje vinograde. Te njihove klijeti su izgledale kao kuće. Gore je bilo su imali i vodu i struju u svakoj klijeti, a nakon postavljanja granice svi su dobili granične propusnice.« Z. M. iz Osunje prisjeća se da su Žumberčani imali zemlju i vinograde u Sloveniji u okolici Prušnje Vasi. "Imali smo i vinograde u Vinjaru i Gradnju.» I. G. (Grdanjci) govori o tome kako su mnogi Žumberčani imali zemlju u Sloveniji: "Imali smo zemlju od Obrežja do Jesenica na Dolenjskem. Znam da je moj deda kupio zemlju od posljednje vlasnice Mokrica. Do 1995. sam obrađivao tu zemlju.»

I povijesna su događanja promatrani kraj značajno oblikovala. To su prije svega događaji povezani s Drugim svjetskim ratom. Tako je J. J. (Jelenići) ostala duboko u sjećanju najteža povreda dobrih međuljudskih odnosa između Hrvata i Slovenaca 1942. godine kada je »selo Planina na slovenskoj strani nastradalo od ustaša uz blagoslov Talijana. Tamo su poubijani bili i naši i Slovenci. Mi danas odlazimo na komemoracije u to selo, ali Slovenci kada dolazimo ne žele izaći van iz svojih kuća. Bila je to najteža povreda međuljudskih odnosa između jednih i drugih. Oni nam i danas taj zločin zamjeraju."

Život na prostoru Žumberka, kako je već u uvodu naglašeno, bio je težak, te je to zbog različitih razloga kraj koji je iznimno izložen depopulaciji. Tako se u 40 godina broj stanovnika Žumberka smanjio čak za 74\%, s 8131 na 2127 (Popović i Radeljak, 2011.: 184). Emigracija iz Žumberka traje kontinuirano od 19. stoljeća do današnjih dana. Puno je razloga za odlaske stanovništva.

I. Š. (Budinjak) emigraciju povezuje i sa svojom obitelji: „Moja tri bratića su tako išli u srednje škole u Ljubljanu. Ljudima na Žumberku nikako nije bio olakšavan život. Loša infrastruktura te nikakvi poticaji za bavljenje poljoprivredom i stočarstvom dovodili su do iseljavanja mladih ljudi. Sjećam se da su u Osunji na slovenskoj granici otkupljivali mlijeko, ali da Dukat nije isplaćivao naknade, pa su ljudi odustajali od bavljenja stočarstvom.»

I. Š. (Budinjak) govori o tome kako su djeca sa Žumberka odlazila služiti u bogatije krajeve u Sloveniju: »Kako kod nas u Žumberku nije bilo zemlje, mnoga su djeca odlazila služiti u Sloveniju. Tako je brat od žene iz sela Grič otišao kao dječak služiti u Trbovlje, ali kako je bio premlad poslali su ga kući. Međutim, vraćajući se kući stao je u selu Maharovec zapadno od Šentjerneja. Jedan mu je gostioničar ponudio da ostane kod njega ako želi hraniti krave.» 
I I. H. (Samobor) govori o iseljavanju sa Žumberka: »To da je mnogo ljudi otišlo na školovanje u Sloveniju je činjenica. Odlazili su u Ljubljanu, a postali su zidari, kovači i malo ih se vratilo." Zlatko Marinković je dobro primijetio kako su u slovenskim selima na Gorjancima i pod Gorjancima stanovnici ostali, dok je Žumberak zahvatila depopulacija. »U njihovim selima svako kućanstvo ima vodovodnu mrežu te su izgrađeni putevi. Osim toga u svako naselje odlazi autobus. Kod nas toga nema.«

\section{Granica i migracije u Sloveniju}

Promjene su osjetili i stanovnici pograničnog prostora. Tako je kazivač I. G. (Grdanjci) o promjenama rekao sljedeće:

"Nakon postavljanja granice mnogo se toga promijenilo. Ljudi su počeli odustajati od druženja. Nekada su mnogi od nas radili u Remontu u Slovenskoj Vasi. Međutim, brojni su dobili otkaze. Više nije bilo ni odlaska u Brežice na sajmove niti su oni toliko dolazili k nama u Samobor. Posije rata i razdvajanja više nema ni slovenskih snaha. Znate, niti jedna više nakon rata nije došla u ovaj naš kraj. Još se uvijek posjećuju obitelji koje su se nekada povezale, prije rata, ali sada više nema novih veza. Kod nas su i svi iz Slovenske Vasi dolazili u trgovinu. Sada više toga nema. Liječnici i rodilište bili su nam u Brežicama. Većina Grdanjčana je rođena u Brežicama.»

M. V. (Stojdraga) smatra da nije samo granica kriva zbog sve manjeg broja kontakata Slovenaca i Hrvata, već da je tome krivo iseljavanje sa Žumberka:

»Nakon uspostavljanja granice prestalo je intenzivno druženje Hrvata i Slovenaca. Međutim, na to nije utjecala granica, već je na to utjecala činjenica da na Žumberku više nema ljudi, da je stanovništvo staro i da dolazi do izumiranja naselja. Oni koji su imali u Sloveniji vinograde prestali su ih obrađivati zbog toga što su ostarili, a ne zbog postavljanja granice. Sajmovi su se prestali održavati zbog toga što nitko na Žumberku više nije mogao držati stoku. Ekonomski se više nije isplatilo održavati sajmove.»

Brojni su Žumberčani koji su bili zaposleni u Sloveniji nakon 1991. i razdvajanja Hrvatske i Slovenije ostajali bez zaposlenja. Od 1986. do 1991. Z. M. (Osunja) radio je u Pioniru u Drnovu nedaleko Brežica. "Nas četvorica smo odlazili iz Osunje i jedan iz Cerovice na posao u Drnovo preko Prušnje Vasi. Kada je 1991. godine došlo do osamostaljivanja Hrvatske i Slovenije svi smo dobili otkaze. Tamo sam naučio dobro slovenski, pa sada sa Slovencima govorim slovenskim jezikom." 


\section{Zaključak}

Prema iznesenim podacima dobivenima iz matičnih knjiga, ali i iz podataka prikupljenih od kazivača, vidljivo je da je suživot na promatranom području bio vrlo bogat te da je uvođenje tvrde granice prekinulo neke procese koji su bili vrlo razvijeni. $U$ prošlosti je suživot obuhvaćao različite segmente svakodnevnog života, na što je ujedno i utjecao. Povezivanje stanovništva na promatranom prostoru događalo se zbog ekonomskih (sajmovi), vjerskih (proštenja), ali i privatnih razloga (ženidbene veze).

Naglasak je na problemima prije svega stanovnika Žumberka, koji su s granicom postali još odsječniji od različitih za život važnih institucija. Uspostava granice kakva je danas izmijenila je obiteljske i prijateljske veze, utjecala je na sve čimbenike koji su u prošlosti bili prepoznati kao vezni segmenti preko kojih je promatrani prostor zapravo tvorio jedinstven povijesno-društveno-kulturni prostor.

Pa opet, iako se ima osjećaj da su pogranične veze i način života u slovensko-hrvatskim pograničnim krajevima posvuda slični, svejedno se u ovom primjeru vidjelo određeno odstupanje. Ono je uzrokovano prije svega odnosima rimokatoličkog i grkokatoličkog stanovništva, gdje su se mladi zbog različitih vjera teže odlučivali na sklapanje ženidbenih veza, a što je potom utjecalo i na obiteljske veze. Druga važna činjenica jesu vrlo loše prometne veze, koje su također utjecale na svakodnevni suživot.

Općenito gledajući situaciju, treba istaknuti da se stanovništvo pograničnog prostora međusobno pomagalo, da su izgradili komplicirane i višeslojne veze, koje djelomično postoje i danas, ali i da su jedni od drugih prihvaćali ono najbolje. 


\section{Literatura}

1. Badovinac, N. (1896). Žumberak i Marindol, Zagreb: Dion. tisk.

2. Balkovec, B. (2003). Paberki o rojstvu in porokah v župniji Preloka. Kronika, 1: 51-60.

3. Bertoša, S. (2001). Doseljenici iz Kopra i njegove okolice u matičnim knjigama od 1613. do 1817. Acta Histriae, 9 (2): 389-414.

4. Bertoša, S. (2001). Puljske matične knjige kao izvor za povijest migracija: doseljenici iz središnje Hrvatske, Ugarske i slovenskih zemalja pod austrijskom vlašću (1613.-1817.). Povijesni prilozi, 19: 181-198.

5. Bertoša, S. (2012). Migracije prema Puli: primjer austrijske Istre u novom vijeku. Pazin: Katedra Čakavskog sabora.

6. Bilotas, V. (2016). The Number of roman Catholics in the Asian Part od the Russian Empire and the Geography of Settlements According to 1859-1865 Status Animarum. Soter, 85 (57): 77-87.

7. Bognar, H. I. i Bognar. A. (2010). Povijesni razvoj i političko-geografska obilježja granice i pograničja Republike Hrvatske s Republikom Slovenijom na Žumberku i u Kupsko-čabranskoj dolini. Geoadria, 15 (1): 187-224.

8. Bračika, M. (2015). Zemljepisni položaj in zgodovinska vloga Žumberka v Vojni krajini ter ljudska kultura Žumberčanov. Metlika: KUD Žumberak.

9. Crkvenčić, I. (2002). Žumberačka Gora - Transformation from a Refuge to an Exodus Zone. Migracijske i etničke teme, 18 (4): 289-306.

10. Čapo-Žmegač, J. (2006). Povratak na granicu: migracijska iskustva u trokutu Hrvatska-Njemačka-Slovenija. Dve domovini, 25: 89-108.

11. Hranilović, N. (1990). Žumberčani - subetnička grupa u Hrvata. Migracijske teme, 5 (4): 593-612.

12. Jagarić, V. (2008). Krvavi kamen na Gorjancima. Žumberački krijes, 2008.: 240242.

13. Josipovič, D. i Kržišnik Bukić V. (2010). Slovensko-hrvaški obmejni prostor: etnične vzporednice med popisi prebivalstva po letu 1991. Ljubljana: Inštitut za narodnostna vprašnja.

14. Kekić, N. N. (1992). Kratki povijesni pregled župe Kalje. Žumberački krijes, 1992.: 38-66.

15. Kekić, N. N. (1994). Stanje župe Mrzlo Polje krajem 18. stoljeća. Žumberački krijes, 1994: 90-94.

16. Klemenčič, V. (2001). Slovensko hrvaška obmejna regija in njene funkcije v povezovanju med Hrvaško in Slovenijo in v luči Evropske integracije. Dela, 16: 7-16.

17. Klemenčić, M. (1989). Historijsko-geografska osnova regionalnog poimanja i demografskih promjena Žumberka. Magistarski rad, Geografski odsjek Prirodoslovnomatematičkog fakulteta u Zagrebu. Zagreb.

18. Knežević-Hočevar, D. (1996). Nekatere dileme oblikovanja konceptov meje in mejnosti. Teorija in praksa, 33 (1): 7-17. 
19. Kržišnik Bukić, V. (1997). Narodnostna sestava v obmejnem prostoru med Slovenijo in Hrvaško. Ljubljana: Inštitut za narodnostna vprašanja

20. Kržišnik Bukić, V. (ur.) (1999). Slovensko-hrvaški obmejni prostor: življenje ob meji. Ljubljana: Inštitut za narodnostna vprašanja.

21. Muraj, A. (1989). Živim znači stanujem: etnološka studija o kulturi stanovanja u žumberačkim Sošicama. Zagreb: Hrvatsko etnološko društvo.

22. Pavković, I. (1987). Kratki povijesni pregled župe Sošice. Žumberački krijes, 1987.: 34-74.

23. Pavković, I. (1988). Kratki povijesni pregled župe Mrzlo Polje. Žumberački krijes, 1988: 48-83

24. Pavković, I. (1990). Kratki povijesni pregled župe Stojdraga. Žumberački krijes, 1990.: 39-67.

25. Po Žumberku in Gorjancih (1989). Novo Mesto.

26. Popović, A. i Radeljak, P. (2011). Razvojni problemi pograničnog pojasa Žumberka. Hrvatski geografski glasnik, 73 (2): 179-199.

27. Popović, M. (1938). Žumberački dijalekt. Zagreb: Tiskara narodnih novina.

28. Riman, B., Škiljan, F. (2018). Rijeka i planina, granica i ljudi: studija slučaja života pograničnog stanovništva Donjekupske doline i Žumberačkog gorja. Historijski zbornik, LXXI (2): 401-439.

29. Severović, N. (2000). Sjećanja jedne žumberačke učiteljice. Žumberački krijes, 2000.: 91-94.

30. Šćukanec, A. (2017). Priče iz zaboravljenog kraja, Jezične biografije transmigranata iz Žumberka. Zagreb: Srednja Europa.

31. Š̈övegeš Lipovšek, G. (2001). Prebivalstvo Lendave na podlagi matičnih knjig med 1909 in 1919. Casopis za zgodovino in narodopisje, 72 (1/2): 97-121.

32. Štambuk, M. (1996). Sociodemografske prilike u Žumberku. Žumberački krijes, 1996.: 139-151.

33. Tesser, L. M. (2013). Ethnic cleansing and the European Union: an interdisciplinary approach to security, memory and ethnography. New York (NY): Basingstoke.

34. Turk, I.; Šimunić, N. i Živić, D. (2016). Prometna dostupnost kao čimbenik depopulacije i razvojnog zaostajanja: primjer Žumberka. Društvena istraživanja, 25 (2): 241-266.

35. Uhač, J. (1996). Marčanska biskupija (eparhija). Neki povijesno-pravni pogledi. Zagreb: Glas koncila.

36. Vlahov, D. (1994). Matične knjige u povijesnom arhivu u Pazinu. Vjesnik istarskog arhiva, 2-3 (1992.-1993.): 277-309.

37. Vukšić, D. (2015). Žumberački uskoci, Unijaćenje i odnarođivanje. Zagreb: Srpsko narodno vijeće.

38. Zajc, M. (2008). Gdje slovensko prestaje, a hrvatsko počinje, Slovensko-hrvatska granica u XIX. i početkom XX. stoljeća. Zagreb: Srednja Europa.

39. Žumberački Uskoci, vjekovni branitelji kršćanstva i Lijepe naše (2018). Sošice: Udruga Žumberački uskoci. 


\section{Internetska stranica}

Od petka obustava dnevne migracije radnika iz Hrvatske u Belu Krajinu https://www. tportal.hr/vijesti/clanak/od-petka-obustava-dnevne-migracije-radnika-iz-hrvatske-ubelu-krajinu-20200312

\section{Kazivači}

G., I., 1954.g., Samobor (sada Grdanjci)

H., I., 1945.g., Samobor

J., J., 1948.g., Jelenići (Budinjak) (sada Samobor)

M., D., 1929.g., Osunja

M., Z., 1960.g., Osunja

Š., I., 1943.g., Šimraki (sada Samobor)

Š., S., 1952.g., Hartje

Š., I., 1960.g., Budinjak (sada Samobor)

V., M., 1951.g., Novo Mesto (sada Stojdraga)

\section{Izvori}

HDA, Matična knjiga umrlih Kalje 1858.- 1878., 1878.-1887., 1888.-1920., 1921.1926.

HDA, Matična knjiga umrlih Mrzlo Polje 1858.-1879., 1879.-1896., 1897-1949.

HDA, Matična knjiga umrlih Sošice 1885.-1940.

HDA, Matična knjiga umrlih župe Stojdraga 1880, 1885.-1901., 1903.-1939.

HDA, Matična knjiga vjenčanih Kalje 1888.-1949.

HDA, Matična knjiga vjenčanih Mrzlo Polje 1858.-1879., 1879.-1896., 1897-1949.

HDA, Matična knjiga vjenčanih Sošice 1885.-1940.

HDA, Matična knjiga vjenčanih župe Stojdraga 1885.-1901., 1903.-1939. 
Izvorni znanstveni rad

\title{
Croatian-Slovenian Relations in the Eastern Žumberak Area
}

\author{
Filip Škiljan
}

Institute for Migration and Ethnic Studies, Zagreb, Croatia

e-mail: filipskiljan@yahoo.co.uk

Barbara Riman

Institute for Ethnic Studies, Ljubljana, Slovenia

e-mail: barbara.riman@gmail.com

\begin{abstract}
The authors provide information on Croatian-Slovenian relations in the Žumberak. The area of the border in scientific terms has been very rarely viewed through the testimonies of people living in the border area, and therefore this research is different, since it is based on the experience of people living along the Croatian-Slovenian border. The study found that residents on both sides of the border were much more oriented towards each other than connected to their regional centers. The border has greatly disrupted relations between Croats and Slovenes on both sides. This paper seeks to show in what ways there were links between one space and another, and how much those links were broken after the 1991 border was established. The research applied the historical and ethnological approach that is evident from the collection of data from the registers of the deceased and the married, or from the method of oral history and storytelling. Based on the registers of deceased and married parishes in Stojdraga, Mrzlo Polje, Sošice and Kalje, the author provides information on the intensity of contacts between Croats and Slovenes in the border zone of Žumberak. It can be seen that these links have been tight over a nearly five hundred-year history in the common state, but that marital relationships were limited because of differences in religion. Interviews conducted in the area of the City of Samobor and the Municipality of Žumberak show that the inhabitants of the border zones have always been economically, socially and family-related to nearby Slovenia.
\end{abstract}

Key words: Žumberak, Croatian-Slovenian relations, Sošice, Samobor, border zone. 